\title{
Quantitative assessment of the foot and ankle during locomotion
}

\author{
Ayak ve ayak bileğinin yürüme aşamasında kantitatif değerlendirilmesi \\ Joseph Krzak ${ }^{1,2}$, Adam Graf', Haluk Altıok ${ }^{1,3}$ \\ 'Shriners Hospitals for Children, Chicago, IL, USA \\ ${ }^{2}$ Midwestern University, College of Health Sciences, Physical Therapy Program, Downers Grove, IL, USA \\ ${ }^{3}$ Rush University Medical Center, Chicago, IL, USA
}

\section{Giriş̧}

Yürüme, hem hareketlilik hem de stabilite yakalamak amacıyla çalışan alt ekstremite segmentlerinin tekrarlı sekansından oluşur. Ayak ve ayak bileği, insan yürümesinin gövde ve destek yüzeyi arasındaki birincil arayüz olarak görev alan tamamlayıcı parçalarıdır. Eklemler, ilk temas anında kuwveti emmek adına hareketlilik ve vücut duruşu değiştikçe stabilite sağlamakta görevlidirler.

Ayak ve ayak bileğinin yürümeye olan katkılarını incelemek, bireylerin yürümeyi nasıl kontrol ettiği ve nöromusküler/musküloskeletal uyumsuzluk ve bozukluklar arasındaki ilişki hakkında derinlemesine bir bakış sağlar. Örnek olarak, serepral palsiye (SP) ikincil olarak ekinovarus veya planovalgus ayak deformitelerinin görüldüğü çocukları incelemek, distal kas sisteminin motor bozuklukları arasında ilişkilendirmeyi ve bu popülasyonda sıklıkla görülen lokomotor kinematik değişimleri görmeye olanak verir. Ayak hakkında çalışırken dikkate alınması gereken sorunlardan biri de sıklıkla kullanılan yürüme analizi modellerinin ayağ basitleştirip tek bir katı segmentmiş gibi göstererek yürüyüş analizini tanımlamak için yeterli veri sunmamasıdır. Ayağın ince hareketlerini takip edebilmek ve yürüyüş sırasında pozisyonlandırmayı yapabilmek için daha kompleks, çok-segmentli bir ayak modeline ihtiyaç duyulmaktadır.

Bu yazının amacı, ayak biyomekaniğini ve yürüyüş sırasında sayısal ölçüm yapmak için kullanılan metodları açıklamaktır. Milwaukee Ayak Modeli (MAM) dahil olmak üzere spesifik çok-segmentli kinematik ayak modelleri teknik olarak açıklanmıştır. MAM'ın pediatrik ayak patolojisine uyarlanması, ayak ve ayak bileği hareket analizinin nasıl hasta bakımında kullanıldığını göstermek adına olgu örnekleri kullanılarak sunulacaktır.

\section{INTRODUCTION}

Locomotion consists of a repetitive sequence of multisegment lower extremity movements functioning to simultaneously achieve both mobility and stability. The foot and ankle are integral components in human locomotion, and they serve as the primary interface between the individual and the support surface. The joints allow for mobility to absorb forces at the point of initial contact and stability as the body advances during stance phase.

Studying the contributions of the foot and ankle to locomotion provides vital insight into how individuals control locomotion and associations between neuromuscular/musculoskeletal impairments and movement dysfunction. For example, studying children with equinovarus or planovalgus foot deformities secondary to cerebral palsy (CP) provides an association between motor dysfunction of distal musculature and alterations in locomotor kinematics common to this population. One problem to consider when studying the foot is that commonly used gait models over-simplify the foot as one rigid segment providing inadequate data to identify where specific gait abnormalities occur within the foot. A more complex, multisegment foot model is needed to track properly subtle foot motion and positioning during gait.

The purpose of this review is to describe foot biomechanics, and the current methods used to quantitatively evaluate foot motion during gait. Specific multi-segment kinematic foot models including the Milwaukee Foot Model (MFM) will be technically described. The application of MFM to pediatric foot pathology will be presented using case examples to demonstrate how motion analysis of the foot and ankle can be applied to patient care.

- Iletişim adresi / Correspondance: Haluk Altıok, Chicago Shriners Hospital, 2211 N. Oak Park Ave., Chicago, 60707, IL, USA

Tel/Phone: USA-773-385-5493 e-posta/e-mail: haltiok@shrinenet.org

- Geliş tarihi/Received: 23 Temmuz/July 2014 Kabul tarihi/Accepted: 23 Temmuz/July 2014 


\section{AYAK BIYOMEKANIĞi}

Perry ve Burnfield'a göre, yürüme sırasında ağırlık taşıyan uzuvlar dört farklı fonksiyon yerine getirir: 1) sürekli değişim gösteren postüre rağmen vücut dikliğini koruma, 2) seçici postür, kas kuvveti, ve tendon elastisitesi etkileşimi sonucu ilerleme sağlama, 3) her adım sırasında zemin darbesini minimalize etme ve 4) bu fonksiyonların yerine getirilmesi için gereken kas gücünü minimuma indirerek enerji korunumu sağlama. ${ }^{[1]} \mathrm{Bu}$ dört fonksiyonun simültane olarak yerine getirilmesi, üst ve alt vücudun bir seri kompleks etkileşimi sonucu belirli hareket dizilerinin ortaya çıkmasıyla oluşur. Ayak ve ayak bileği, proksimal segmentlere mekanik bağlantı olmakla beraber bireysel yüzey ve destek yüzeyi arasında arayüz görevi görerek bu fonksiyonlarda tamamlayıcı bir rol oynar.

Yürüme sırasında ayak, enerji harcanmasını minimize ederken hem stabilite hem de hareketlilik sağlamak için bir dizi karmaşık fonksiyonu yerine getirmelidir. Ayak ve ayak bileği boyunca stabilite sağlamak somatosensoriyel geri bildirim, eklem hareketliliği, ve kas kontrolünün birleşimini gerektirir. Yürüme sırasında ayak, duruş fazı da denilen, destek zeminiyle temas halindeyken daha proksimaldeki uvuz segmentlerinin rotasyonunu arttırarak ilerleme esnasında daha stabil bir zemin yaratıp proksimal kasların eforunu minimuma indirir. ${ }^{[2]}$ Ayak içerisindeki yapıların esneyebilirliği, destek yüzeyiyle temas anı ve zemin değişikliklerinde kuvvet emilimini sağlar.

Duruş fazının ayak topuğunun yere vurmasıyla başlayan ilk aşamasında, topuk vuruşundan düz ayağa, tibianın internal rotasyonu subtalar eklemde ani eversiyonla sonuçlanır. Subtalar eversiyon, talokrural ve subtalar eklemin sıra dışı ilişkisinden dolayı olur. Talokrural eklemin deneysel aksı (mediyal malleol başından lateral malleole kadar) koronal düzlemde tibianın dikey aksına $\sim 82^{\circ}$ oblik olarak yönlendirilmiştir. Bu, ayak bileği sagittal düzlemde hareket ederken beraberinde ayak veya bacakta horizontal rotasyona izin verir. Basitçe subtalar eklemin köşeli menteşe gibi davrandığını düşünebiliriz. Aksı yatayda $\sim 42^{\circ}$, sagittal düzlemde $\sim 16^{\circ}$ plantar-lateralden dorso-mediyale oblik olarak uzanır (Şekil 1). Bu obliklik tibianın aksiyel rotasyonunun subtalar eklemde eversiyon/inversiyona ve orta-ön ayakta pronasyon/supinasyona dönüşmesini sağlar. Böylelikle subtalar eklem eversiyona geldiğinde transvers tarsal eklemler (kalkaneoküboid ve talonaviküler eklemler) akslarını paralel hale getirerek çözülürler. Transvers tarsal eklemlerin çözülmesi, ayak ve mediyal arkın yüklenme sırasında vücut ağırlığını taşımasını ve ayağın eşit olmayan yüzeylere uyumunu sağlayan bir esneklikle sonuçlanır. ${ }^{[3,4]}$

\section{FOOT BIOMECHANICS}

According to Perry and Burnfield, during locomotion each weight-bearing limb accomplishes the four distinct functions: 1) upright stability is maintained despite an ever-changing posture, 2) progression is generated by the interaction of selective postures, muscle force, and tendon elasticity, 3) floor impact at the onset of each stride is minimized, 4) energy is conserved by these functions being performed in a manner that reduces the amount of muscular effort required. ${ }^{[1]}$ The simultaneous accomplishment of these four functions depends on distinct motion patterns which represent a complex series of interactions between the upper and lower body. The foot and ankle play an integral role in these functions acting as the principal interface between the individual and the support surface, as well as a mechanical link to more proximal segments.

During locomotion, the foot is required to perform a number of intricate functions allowing for both stability and mobility while minimizing energy expenditure. Stability throughout the foot and ankle requires the integration of somatosensory feedback, joint mobility, and muscle control. While the foot is in contact with the support surface during locomotion, referred to as stance phase, it propagates rotation of more proximal limb segments and minimizes effort of more proximal muscles by providing a stable base during forward progression. ${ }^{[2]}$ Flexibility of the structures within the foot allows it to absorb forces at initial contact with the support surface and accommodate to alterations in terrain.

During the first rocker of stance phase, from heel strike to foot flat, internal rotation of the tibia result in rapid eversion of subtalar joint. Subtalar eversion occurs because of the unique relationship between the talocrural and subtalar joints. The empirical axis of talocrural joint (from the tip of medial malleoli to lateral malleoli) is oriented obliquely at $\sim 82^{\circ}$ from the vertical axis of the tibia in the coronal plane. This allows concomitant horizontal rotation to occur in the foot or leg as the ankle moves in the sagittal plane. A simplified analogy is that the subtalar joint acts like a mitered hinge. Its axis passes obliquely from a plantarlateral to dorso-medial direction $\sim 42^{\circ}$ up from horizontal and from the sagittal plane $\sim 16^{\circ}$ (Fig. 1). Such obliquity allows the axial rotation of the tibia to be translated into eversion/inversion of the subtalar joint and subsequent pronation/supination of the midfoot and forefoot. Thus, when the subtalar joint everts, the transverse tarsal joints (calcaneocuboid and talonavicular joints) unlock bringing their axes parallel to each other. Unlocking of the transverse tarsal joints results in a suppleness which allows the foot and medial arch to absorb the impact of the body weight during 

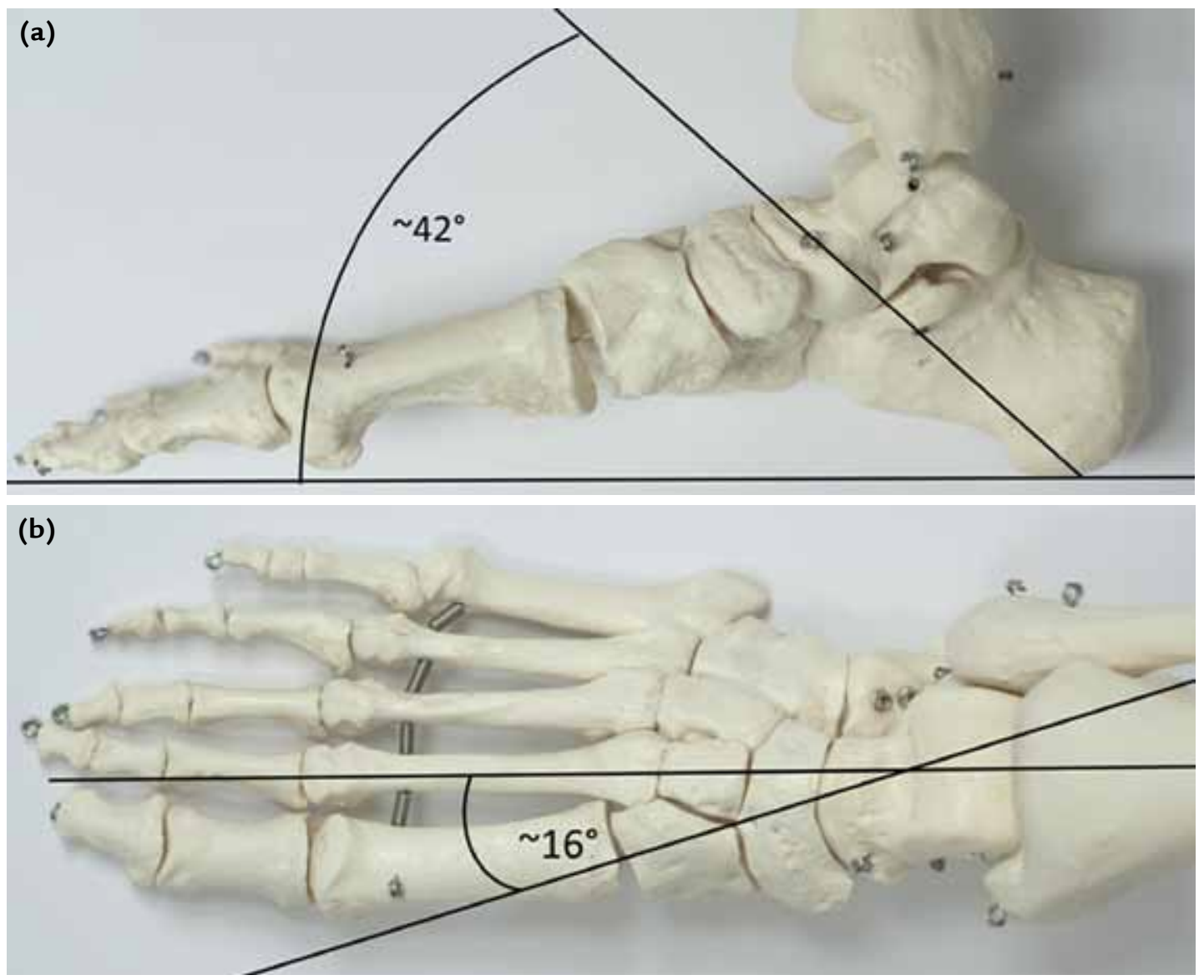

Şekil 1. a, b. Subtalar eklemin aksı sagittal düzlemde yaklaşık $42^{\circ}$ (a) ve yatay düzlemde yaklaşık $16^{\circ}$ (b) olarak görülmektedir.
Figure 1. a, b. The axis of the subtalar joint lies at approximately $42^{\circ}$ in the sagittal plane (a) and at $16^{\circ}$ in the horizontal plane (b).
Duruş fazının ayağın yer ile tam teması ile başlayan ikinci aşamasında ayak plantigrad ve ayak bileği gittikçe dorsifleksiyona yaklaşmaktadır. Tibial eksternal rotasyona ikincil olarak subtalar eklem inversiyona gelmektedir. Subtalar eklem inversiyonu distale doğru yayılarak kalkaneoküboid ve talonaviküler eklemlerin transvers tarsal atrikülasyonun stabilitesini arttırıp kilitlenmeyi sağlar. Bu sayede esnek orta ayak daha sert bir yapıya dönüşserek proksimal segmentler için sabit bir yüzey oluşturur. ${ }^{[3,4]}$

Duruş fazının topuğun yerden ayrılması ile başlayan ve ayak parmaklarının yerden ayrılması ile son bulan üçüncü aşamasında ayak bileği plantar fleksiyon ve ileri eksternal tibial rotasyon gösterir. Subtalar eklem inversiyona devam ederek ayak parmaklarının yerden ayrılması aşamasında maksimuma ulaşır. Distalde tarsal eklemler sert segmentlere dönüşerek güç jenerasyonu ve ileri atılım sağlar.

Biyomekanik ve/veya nöromusküler ayak ve ayak bileği fonksiyon bozuklukları yukarıdaki normal loading response and also allows the foot to adjust to uneven surfaces. ${ }^{[3,4]}$

During second rocker, the foot is plantigrade and the ankle joint progressively dorsiflexes. The subtalar joint progressively inverts secondary to tibial external rotation. This subtalar joint inversion propagates distally locking the calcaneocuboid and talonavicular joints which increases the stability of the transverse tarsal articulation. This helps to transform the flexible midfoot to a rigid structure providing a stable base for the more proximal segments. ${ }^{[3,4]}$

During the third rocker, the ankle joint demonstrates rapid plantar flexion and further external tibial rotation. The subtalar joint continues to invert, reaching its maximum at toe-off. Distally, the tarsal joints are transformed into a rigid segment to facilitate power generation and forward propulsion. ${ }^{[3,4]}$

The presence of biomechanical and/or neuromuscular foot and ankle dysfunction can impact any or all of the 
yürüme durumlarından bir veya birden fazlası$\mathrm{n}$ etkileyebilir. Bu şekilde segmentlerin birbiriyle bağlantılı olduğu durumlarda bir segmentin etkilenmesi diğerlerinin de etkilenmesine yol açabilir. Stebbins ve arkadaşları, tipik olmayan ayak ve ayak bileği hareketlerinin ve ardından yapılan cerrahi düzeltmelerin alt ekstremitede yürüme sırasında daha proksimal segmentlerin hareketini etkilediğini göz önüne koymuştur. ${ }^{[5]}$ Biyomekanik zincirde meydana gelen her bozukluk, hareketin yanı sıra fonksiyonel engellere de yol açabilir. Ballaz ve arkadaşları, yürüme sırasında ayak kinematiği tepe noktası ile enerji harcanmasıyla beraber hareket değişiminin bağlantısını göstermiştir. ${ }^{[6]}$ Motor kontrolü etkileyen nöromusküler hastalıklar sonucu meydana gelen ayak ve ayak bileği fonksiyon bozukluklarının incelendiği her iki çalışmada da SP'li çocuk ve adolesan kullanılmıştır.

\section{YÜRÜME ANALIZi}

Sayısal yürüme analizi genel olarak yürüme sırasında temporal-boyutsal, kinematik, kinetik ve elektromiyografik (EMG) verilerin ardışık elde edilmesini içerir. Asırlardır kullanılan sayısal yürüme analizi belirli hastalık evrelerinin takip edilmesi, ortopedik cerrahinin yararı hakkında objektif data sunması, ve klinisyenlere uygun müdahale kararı almada yardımcı olması açısından önemli bir yer tutar. ${ }^{[7]}$

On yıllardır yürüme sırasında ayak ve ayak bileği kinematiğini ölçerken ayak, ayak bileği etrafında dönen tek bir segmentmiş gibi gösterilmiştir. ${ }^{[8]}$ Proksimal ve distal segmentler tibia ve ayak olarak tanımlanırken tibianın lateral şaftına, lateral malleole, ve ikinci ve üçüncü metatars arasına markır yerleştirilir. Sonuç olarak bu şekilde yapılan ölçümler iki-boyutludur ve sagittal düzlemde plantar/ dorsifleksiyon ayağın tibiaya göre ölçümünden, transvers düzlemde ayak rotasyonunun tibiaya gore ölçümünden, ve global kordinat eksenlere göre ayağın transvers düzlemde yaptığı ilerleme açısından oluşur. ${ }^{[8-10]}$

Yirmi sekiz kemik, ayrıntılı artikülasyon, ve yüzlerce bağ ve kas bulunan ayağın, biyomekanikte tek bir segmentmiş gibi gösterilmesinin basite indirgemek olduğu yaygın olarak kabul edilmiştir. ${ }^{[11]}$ Ayağın hareket analizinde tek bir segment halinde gösterilmesi, ayak içerisinde oluşan deformitelerin gözden kaçmasına neden olabilir. Ayrıca ayak ve ayak bileğinde tanımlanan deformitelerin tek bir eklemle bağdaştırılması mümkün olmayabilir. Bu yüzden yürüyüş sırasında ayak ve ayak bileğinin above aspects of normal locomotion. Whenever there are segments directly linked together an abnormality in any one segment can propagate up or down the chain affecting segments several links away. Stebbins et al. demonstrated that atypical foot and ankle motion and subsequent surgical correction impacted motion of the more proximal segments of the lower extremities during locomotion..$^{[5]}$ Any disruptions in the biomechanical chain can not only impact movement but can also lead to functional disabilities. Ballaz et al. showed moderate correlations of ankle kinematic peaks and excursion of motion with energy expenditure during locomotion. ${ }^{[6]}$ The populations used in each of these studies presented with foot and ankle dysfunction resulting from one of the most prevalent neuromuscular diseases affecting motor control in children and adolescents' CP.

\section{GAIT ANALYSIS}

Quantitative gait analysis typically includes a collection of temporal-spatial, kinematic, kinetic and electromyographic (EMG) data simultaneously collected during locomotion. Quantitative gait analysis has been extensively utilized across ages and pathologies to identify atypical movement patterns, guide clinicians' decisions about appropriate interventions, providing objective data about the efficacy of orthopedic surgery, and longitudinally tracking the progression of various disease processes. ${ }^{[7]}$

For decades, the accepted approach to quantify foot and ankle kinematics during locomotion has been to represent the entire foot as a single rigid body with a revolute ankle joint. ${ }^{[8]}$ The proximal and distal segments are identified as the tibia and the foot with surface markers placed on the lateral shaft of the tibia, lateral malleolus, and in-between the second and third metatarsals. Ultimately, the foot and ankle kinematics calculated using this method are two-dimensional and consist of plantar/dorsiflexion in the sagittal plane with the position of the foot measured in reference to the tibia, foot rotation in the transverse plane in relation to the tibia, and foot progression angle which describes the transverse plane orientation of the foot in relation to the global coordinate axes. ${ }^{[8-10]}$

It is well accepted that referring to the "foot" biomechanically as a single segment is an oversimplification of a structure that contains 28 bones, intricate articulations, and hundreds of ligaments and muscles. ${ }^{[11]}$ Utilization of a single segment model to represent foot motion during gait can potentially neglect to identify a deformity within the foot complex. Also, even when abnormalities are identified within the foot and ankle segments, it is not possible to isolate the problem to a 
karmaşıklığını anlayabilmek adına daha sofistike bir model, gelişmiş sayısal veri ve farklı ayak deformitelerinin etiyolojilerini görmeyi sağlayacaktır.

Ayak ve ayak bileği hareketlerinin segmental kinematiğini izlemek için cilt yüzeyine markır konularak yapılan, hareketin 3 boyutlu görüntüleme teknolojisi ile kaydedilmesinde belirli miktarda iskelet hareketinin cilt yüzeyindeki markırlar tarafından algılanmada başarısız olması eleştirilmiştir. Nester ve arkadaşları, ${ }^{[12]}$ yüzey markırlarının iskelet hareketi ölçme kabiliyetini kadavra uzuvlarında şu üç tekniği kullanarak kinematik karşılaştırması yapmışlardır: 1) direkt olarak cilde yapıştırılan markır, 2) demir plaka üzerine yerleştirilip cilde yapıştırılan markır ve 3 ) kemik pinlerine yapıştırılan markır. Yazarlar bu üç teknik arasındaki lokomotif kinematiklerde kritik bir farklılık görülmediğine karar vermişlerdir. Bu nedenle yürüme sırasında ayak ve ayak bileği biyomekanik modelini geliştirmede pasif markır kullanımı uygun bir metot olarak değerlendirilmelidir.

\section{AYAK VE AYAK BILEĞiNIN SEGMENTAL KINEMATIK ANALIZi}

Rankine ve arkadaşları, yürüme sırasında ayak ve ayak bileği segmentleri hakkında bilgi veren yaklaşık 23 yayımlanmış ayak ve ayak bileği kinematik modeli tanımlamıştır. ${ }^{[9]} \mathrm{Bu}$ modeller ayağı tek bir segmentmiş gibi gösteren modellerden farklı olarak ayak ve ayak bileğini birkaç değişik segmente böldüğünden dolayı ayak hareketlerini daha kesin bir şekilde vermektedir. Bu modelleri birbirinden ayıran etmenler, ayak ve ayak bileğini göstermede kullanılan segment sayısı (2'den 10'a kadar), altta yatan iskelet anatomisine yüzey markırlarını uyarlamada kullanılan matematik metotları (örn. nötral referanslama), ve segmentler arası açıyı ölçmede kullanılan metotlardır (Euler açıları veya Eklem Koordinat Sistemi). ${ }^{[9,13]}$ Örnek olarak, Oxford Ayak Modeli çocuklarda kullanım için uyarlanan dört segmentli bir ayak ve ayak bileği modelidir (tibia, arka ayak, ön ayak, ve halluks). ${ }^{[14,15]}$ Nötral referanslama adına statik veri toplama sırasında ayak ve ayak bileği pozisyonlandırmasını stardart hale getirmek için bir eksternal teknik yapı kullanılır. Segmentler arası kinematik ölçümleri, Euler sistemi kullanılarak, her segmentin anatomik olarak kendinden daha proksimalindeki segment ile karşılaştırılması esasına göre yapılmıştır. Kidder ve arkadaşları tarafından kullanımı pediatrik popülasyon içinde kabul edilmiş Milwaukee Ayak Modeli (MAM) diye adlandırılan bir başka biyomekanik model geliştirilmiştir. ${ }^{[16,17]}$ MAM dört ayak particular joint. Thus, to understand the complexities of the foot and ankle during gait, a more sophisticated model that describes segmental foot and ankle motion would provide improved quantitative data and more insight into the etiology of various foot deformities.

A potential criticism of using 3-D motion capture technology with passive surface markers to track segmental kinematics of the foot and ankle is that there may be a significant amount of skeletal motion occurring under the skin's surface that can fail to be accounted for using this technique. Nester et al. ${ }^{[12]}$ assessed the capability of surface markers to accurately track skeletal motion on cadaver limbs by comparing kinematics collected using three techniques: 1 ) markers attached directly to the skin, 2) markers attached to rigid plates mountred on the skin, and 3) markers attached to bone pins. The authors determined that there was not a ciritical difference between locomotive kinematics between the three different techniques. Thus, the utilization of passive marker sets to develop a biomechanical model of the foot and ankle during locomotion should be considered an appropriate method.

\section{SEGMENTAL KINEMATIC ANALYSIS OF THE FOOT AND ANKLE}

Rankine et al. identified over twenty-three published segmental foot and ankle kinematic models that provide unique information regarding motion of foot and ankle segments during locomotion. ${ }^{[9]}$ These models divide the foot and ankle into multiple segments that more accurately represent the motion of the foot as opposed to the single segment. Factors that distinguish the models include the number of segments used to represent the foot and ankle (ranging from two to ten segments), methods used for mathematically linking the surface marker sets to the underlying skeletal anatomy (i.e. neutral referencing), and methods used to calculate intersegmental angles (Euler angles or the Joint Coordinate System). ${ }^{[9,13]}$ For example, the Oxford Foot Model is a four segment foot and ankle model (tibia, hindfoot, forefoot, and hallux) that has been adapted for use in children. ${ }^{[14,15]}$ An external technical frame is used to standardize the foot and ankle position during the static data collection trial for the purpose of neutral referencing. Intersegmental kinematics are calculated with the segments represented in a distal relative to the next proximal segment relationship using an Euler System. Another biomechanical model has been developed by Kidder et al., referred to as the Milwaukee Foot Model (MFM), and has been validated for use in the pediatric population. ${ }^{[16,17]}$ The MFM provides kinematic data of four foot and ankle segments: tibia, hindfoot, forefoot 
ve ayak bileği segmenti için kinematik veri sağlar: tibia, arka ayak, ön ayak, ve halluks. Milwaukee ayak modeline özgü olan, nötral referans için ayağın yere basılması anında çekilen ön-arka, yan ve arka ayağın koronal düzlem radyografilerinin kullanılmasıdır. ${ }^{[18]}$ Nötral referanslama sırasında statik denemelerden alınan veri koleksiyonu yüzey markırlarını altta yatan iskelet anatomisine matematiksel olarak uyarlamada kullanılır. Bu arka ayak gibi segmentlerin modellemesinde sorun yaratır. Topuk üzerinde koronal ve sagittal düzlem oryantasyonunu sunacak güvenilir kemiksi nokta bulunmamaktadır. Sonuç olarak MAM, radyografilerden alınan ölçümleri önceden konumlandırılmış lokal koordinat eksenlerini altta yatan iskelet anatomisine göre yeniden uyarlayarak kullanır. Bu radyografik ölçümler sadece bireysel segmentlerin hesaplanması için değil, aynı zamanda diğer hareket düzlemlerinin kinematiğinde de önemlidir. ${ }^{[19]} \mathrm{Bu}$ tarz bir tekniğin kullanılması talipes ekinovarus (clubfoot), tarsal koalisyon, SP ile alakalı planovalgus/ekinovarus, ve Charcot-Marie-Tooth gibi hastalıklarda, nötral hiza sağlanması mümkün olmayan belirli ayak deformitelerinde önemini gösterir. Segmentler arası açıyı hesaplamak için segmental kinematikler tibianın global koordinat eksenine göre belirtilir. Geri kalan segmentler ise Euler sistemi kullanılarak yandaki proksimal segmente relatif olarak distalde ifade edilir. Üç-boyutlu hareket hesaplamasında rotasyonların sıralaması sagittal, koronal, ve transvers şekildedir.

\section{Normal ayak ve ayak bileği hareketi}

Tanımlamalar MAM ile toplanan veri koleksiyonuna dayanarak yapılmıştır (Şekil 2). Çocuklarda yürüyüş sırasında ayak ve ayak bileğinin hareketi yetişkinlerle benzer şekil göstermektedir. ${ }^{[20]}$ Milwaukee ayak modelinde, çok segmentli ayak ve ayak bileği kinematikleri, tibianın laboratuvar düzlemine göre referans alınması ile ölçülmüştür. Arka ayak, ön ayak, ve halluks sırasıyla bir sonraki proksimal segmente göre refere edilir. Böylelikle, ayak bileği ve subtalar hareket en iyi, arka ayağın tibiaya göre hareketi şeklinde ifade edilir.

\section{Tibia hareketi}

Tibia yürüyüş sırasında, laboratuvara göre ilk temas anında yaklaşık $18^{\circ}$ posterior açılanma ve ayak havadayken $45^{\circ}$ anterior açılanmayla beraber, $\sim 60^{\circ}$ hareket açıklığına ulaşır. Tibia, ayak ilerleme açısı ve duruştaki internal rotasyonda ağırlık kabulüne göre itme ve ilk salınım esnasında tibia abduksiyon sergiler. and hallux. Unique to the MFM is the use of weight bearing, radiographic offset measurements in anterior/ posterior, lateral, and a unique hindfoot coronal views for the purpose of neutral referencing. ${ }^{[18]}$ During neutral referencing, data collection from the static trial is used to mathematically link the orientation of the surface markers to the underlying skeletal anatomy. This becomes problematic when modeling segments such as the hindfoot. Reliable bony landmarks do not exist on the calcaneus to adequately represent the coronal, and sagittal plane orientation of the hindfoot segment. As a result, the MFM uses the measurements obtained from the radiographs to reorient the embedded segmental local coordinate axes to the orientation of the underlying skeletal segments. These radiographic measures are extremely important to the calculation of not only the offsets of the individual segments but also affect the kinematics in other segments and planes of motion. ${ }^{[19]}$ The importance of utilizing this type of technique becomes more apparent when dealing with significant foot deformities found in the pediatric populations where neutral alignment may be impossible to obtain such as talipes equinovarus (clubfoot), tarsal coalition, planovalgus/ equinovarus associated with $\mathrm{CP}$, and Charcot-MarieTooth. To calculate intersegmental angles, the segmental kinematics are expressed with the tibia referenced to the global coordinate axes. The remaining segments are represented in a distal relative to the next proximal segment relationship using an Euler System. The order of rotations selected for calculation of three-dimensional motion is sagittal, coronal, and then transverse.

\section{Normal foot and ankle motion}

The following descriptions are based on data collected using the MFM model (Fig. 2). Patterns of motion of the foot and ankle during normal gait in children appear to follow closely the pattern for adults. ${ }^{[20]}$ Multisegment foot and ankle kinematics calculated using the MFM reference the tibia to the laboratory. The hindfoot, forefoot and hallux are subsequently referenced to their next proximal segment. Therefore, ankle and subtalar motion is best represented as the motion of hindfoot relative to the tibia.

\section{Tibia motion}

The tibia undergoes $\sim 60^{\circ}$ range of motion (ROM) during the gait cycle with approximately $18^{\circ}$ of posterior angulation in relation to laboratory at initial contact to $45^{\circ}$ of anterior angulation at foot off. The tibia exhibits abduction during push off and initial swing relating to the foot progression angle and internal rotation during stance phase load acceptance. 


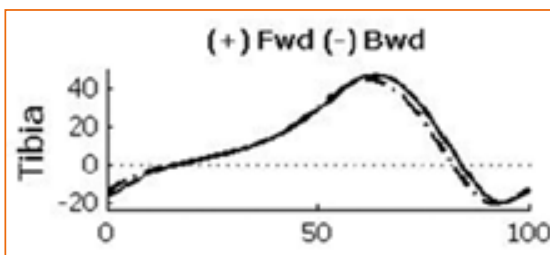

(+) Dorsi (-) Plantar

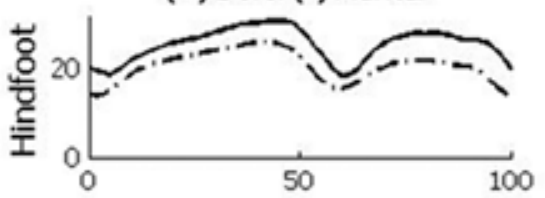

(+) Dorsi (-) Plantar

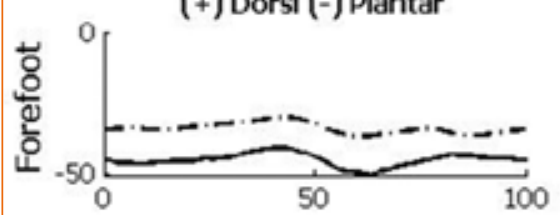

(+) Dorsi (-) Plantar

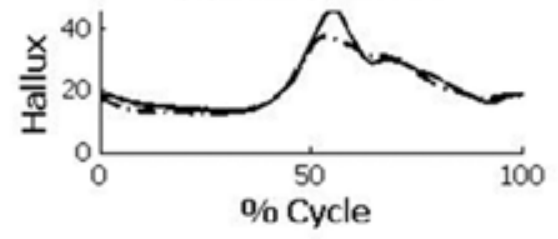

(+) Abduct (-) Adduct

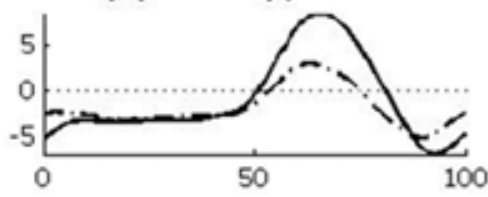

(+) Evers (-) Invers

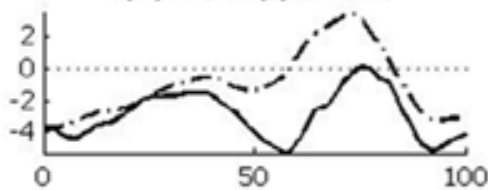

(+) Valgus (-) Varus

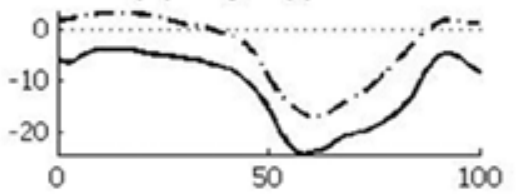

(+) Pronation (-) Supination

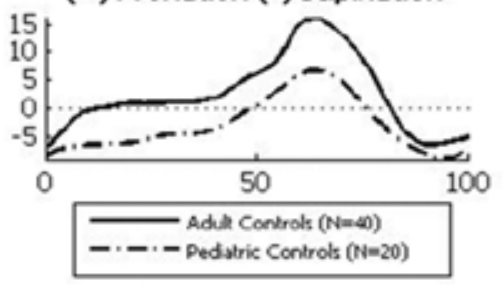

(+) Ext Rot (-) Int Rot

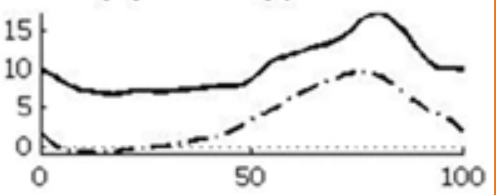

(+) Ext Rot (-) Int Rot

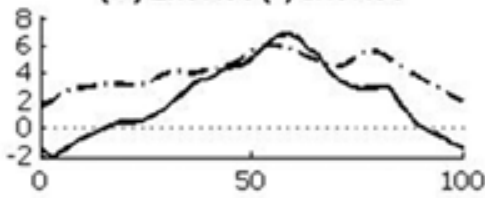

(+) Abduct (-) Adduct

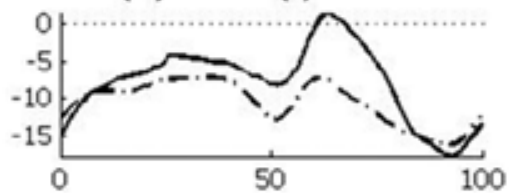

(+) Valgus (-) Varus

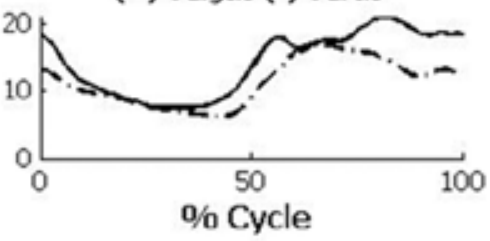

Şekil 2. Ayak ve ayak bileği hareket grafilerinin üç-boyutlu görünümü. Yetişkin kontol ve pediatrik kontrol.
Figure 2. Three dimensional segmental foot and ankle motion graphs. Adult Controls and Pediatric Controls.

\section{Arka ayak hareketi}

Sagittal düzlemde arka ayağın hareketi, tüm vücut yürüyüş analizi sırasında gözlemlenen ayak ve ayak bileğinin basma fazı aşamalarındaki hareket özelliklerine benzerlik gösterir. Koronal ve transvers düzlem grafileri duruş sırasında eversiyonu ve yürüyüş sırasında hafif eksternal rotasyonu kanıtlar. Bu, yük taşımak için gereklidir. Ölçülen eversiyon açıklığı ortalama $4^{\circ}$ 'dir. Inversiyon, duruş fazının sonundan itme fazına kadar devam eder. Salınım fazında ayak bileği dorsifleksiyona gelip topuğu vuruş için hazırlarken tek bir eversiyon-inversiyon döngüsü meydana gelir.

\section{Ön ayak hareketi}

Arka ayakla karşılaştırıldığında sagittal düzlemdeki ön ayak hareketi minimumdur. Daha plantar fleksiyon bir duruş sergiler. Duruş fazının sonundan itme fazının başlangıcından itibaren koronal düzlemde supinasyon meydana gelir. ilk ve yarı-salınım fazında ön ayakta pronasyon ve abduksiyon görülür.

\section{Hindfoot motion}

Sagittal plane motion of the hindfoot demonstrates three rockers similar to the ankle rockers observed during whole-body-gait analysis. The coronal and transverse plane graphs display the eversion of the hindfoot throughout stance and slight external rotation throughout the gait cycle. This is required to accept loading. The measured range of eversion is about $4^{\circ}$ on average. Inversion occurs in late stance and proceeds through push-off. There is a single cycle of eversion and inversion, which occurs during the swing phase as the ankle goes into dorsiflexion and prepares for heel strike.

\section{Forefoot motion}

Sagittal plane forefoot motion is minimal when referenced to the hindfoot. It maintains a relatively plantarflexed position. There is supination in the coronal plane during the last part of stance and just preceding and during push-off. The forefoot pronates and abducts during initial and midswing phase. 


\section{Halluks hareketi}

Halluks duruş fazının sonunda dorsifleksiyonda, ilk temas anında supinasyonda, ve itme fazında yaklaşık $10-15^{\circ}$ 'lik valgusu koruyarak pronasyonda bulunur (Şekil 2).

\section{Çocuklarda ayak ve ayak bileği hareket analizinin klinikte uygulanması}

Çocuklardaki ayak deformitelerinin konjenital kökenliden nöromuskülere kadar uzanan geniş bir spektrumu vardır. Ayak ve ayak bileği hareket analizini pedobarografiye (ayak basıncı) uyarlamak sadece normal yürüyüş ve bunların değişikliklerini çalışmak için değil aynı zamanda tedavi öncesi değerlendirme, cerrahi karar verilmesi ve ameliyat sonrası takipte önemli birer araç haline gelmiştir. Clubfoot deformitesinin uzun dönem sonuçları, SP'de valgus ve varus ayak deformitelerinde tedavi kararı, ve nöromusküler durumlarda kompleks yürüyüş deformitelerinin değerlendirilmesi örnekler arasındadır.

\section{Clubfoot}

Clubfoot nedeniyle tedavi edilen iki grup genç yetişkinin segmental ayak ve ayak bileği hareket analizi, Ponseti yöntemi ve kapsamlı cerrahi gevşetme ile tedavi edilen bireylerde arka ayak hareket açıklığının azalmasıyla beraber arka ayak kinematiğinde plantar fleksiyon ve ön ayakta dorsifleksiyon kayması olduğu gözlemlenmiştir (Şekil 2 and 3). ${ }^{[21]}$

\section{Tarsal koalisyon}

Tarsal koalisyon tarsal kemiklerin bustalar eklem hareketini önleyecek biçimde birleşmesidir. Ameliyat öncesi ve sonrası ayak ve ayak bileği hareket analizlerini incelemek, bizim patolojik problemleri ve ameliyatın hasta memnuniyeti üzerindeki etkisini daha iyi değerlendirmemizi sağlayacaktır (Şekil 4). ${ }^{[22]}$

\section{Serebral palsi}

Serebral Palsi ekinus, planus, varus, valgus ve bunların kombinasyonlarından oluşan ayak ve ayak bileği deformitelerinin görülmesine neden olan nöromusküler bozuklukların en sık görülenidir. Yürüyüş sırasında segmental ayak ve ayak bileği hareket analizi spesifik segmentlerin deformiteleri ve ne derece dahil oldukları hakkında bize bilgi verir.

\section{Ekinovarus ayak deformiteleri}

Varus ayak deformiteleri SP'li çocuklarda ekinusla bağlantılı halde yaygındır. Varus ayak

\section{Hallux motion}

The hallux dorsiflexes during late stance, supinates at initial contact and pronates during push off while maintaining about $10-15^{\circ}$ of valgus throughout the gait cycle (Fig. 2).

\section{Clinical application of foot and ankle motion analysis in children}

There are a wide spectrum of children's foot deformities, which range from congenital to neuromuscular. Applying foot and ankle motion analysis and pedobarography (foot pressures) have become important tools in studying, not only the normal gait events and their variability, but also the pretreatment assessment, surgical decision making, and postoperative follow up of pathologic gait. Long term results of clubfoot deformity, treatment decisions for valgus and varus foot deformities in cerebral palsy, and evaluation of complex gait deformities in neuromuscular conditions are such examples.

\section{Clubfoot}

Segmental foot and ankle motion analysis of two groups of young adults treated for clubfoot revealed that subjects treated using the Ponseti method and those treated with comprehensive surgical release both had a plantar flexion shift in hindfoot kinematics and corresponding dorsiflexion shift in the forefoot kinematics throughout the gait cycle, with decreased hindfoot ROM from terminal stance to preswing (Fig. 2 and 3). ${ }^{[21]}$

\section{Tarsal coalition}

Tarsal coalition is a union of tarsal bones that limits subtalar joint motion. Evaluation of the foot and ankle motion pre- versus post-operatively with foot and ankle gait analysis will increase our ability to understand the pathological problem and the impact of the surgery on the patient satisfaction and outcome (Fig. 4). ${ }^{[22]}$

\section{Cerebral palsy}

Cerebral Palsy is the most common neuromuscular disorder which causes foot and ankle deformities such as equinus, planus, varus, valgus and some combinations of each. Segmental foot and ankle motion analysis during gait can reveal the specific segments involved in the deformity and the magnitude of their contributions.

\section{Equinovarus foot deformities}

Varus foot deformities are common in young children with cerebral palsy and are associated with equinus. Foot and ankle motion analysis and fine wire 
deformitelerinin değerlendirme ve tedavisinde ayak ve ayak bileği hareket analizi, ve kablolu EMG yarar sağlayabilir. ${ }^{[23]}$ Deformitenin görüldüğü faz (salınım ve duruş fazı) ve yürüyüş anormalliklerinin konumu ne zaman ön ayak, ne zaman arka ayak tendon transferi ve uzatması yapılacağı bilgisini arttırır.

\section{OLGU ÖRNEĞi}

Hemiplejik bir SP hastasında sol ayakta ekinovarus ayak deformitesi. Hasta hareket analizi ve kablolu EMG ile değerlendirildikten sonra, split tibialis posteriordan peroneus brevise transfer ve topuk bağ uzatmasıyla tedavi edilmiştir (Şekil 5).

\section{Charcot-Marie-Tooth}

Charcot-Marie-Tooth, çevresel sinir sistemini etkileyen kalıtsal bir durumdur. Hastalar genelde ayak ve bacaklarda ilerleyen kas güçsüzlüğü görürler. Karakteristik özellikleri, ayak düşmesi, pes kavus, intrensek kas güçsüzlüğü ve genelde tendon transferiyle, osteotomiyle ve/veya füzyonla tedavi edilen çekiç parmaktır. Ayak ve ayak bileği hareket analizinin uyarlanması, cerrahi karar verme ve sonuçların değerlendirilmesi açısından anlayışımızı genişletecektir (Şekil 6). ${ }^{[24,25]}$

\section{GELECEK YÖNTEMLER}

Yürüyüş esnasında ayak ve ayak bileği hareket

\section{analizi için floroskopik görüntüleme}

Ayak ve ayak bileği patolojileri konjenital kaynaklıdan nöromuskülere kadar uzanabilir. Dinamik ayak fonksiyonu tedavi edildiği halde radyografiler, bilgisayarlı tomografi (CT) ve manyetik rezonans (MR) görüntüleme cihazları ayak hakkında bize ancak statik görüntüler sunar. Bu teknikler aynı zamanda arka ayağın ön ayağa göre inversiyon/eversiyon ve internal/eksternal rotasyonu sağlayan subtalar eklemin hareketini kesin olarak gözlemlemeye olanak vermez. Ek olarak ayağın ayakkabı, breys veya ortezlerle olan asıl etkileşimini göstermezler. Ayağı yürüyüş sırasında gösterebilecek bir floroskopik sistem, ayağın iç yapılarını ve birbirleriyle etkileşimlerini gerçek zamanlı olarak sunabilir. Son çalışmalar, floroskopik sistemleri zemine monte ederek bireyin alıcılar arasında yürüyüp art arda çekilen görüntülerin bir video oluşturulması yönündedir (Şekil 7). Bu analizden elde edilen bilgiler klinisyenler ve araştırmacılara tipik olmayan segmental ayak hareketlerini tanımlamayı, müdahaleleri planlamayı, gelişmeyi izlemeyi ve uzun dönem bakım vermeyi sağlar.
EMG can be beneficial for evaluation and treatment of varus foot deformities. ${ }^{[23]}$ Knowledge of the phase of the deformity (swing versus stance phase) and location of gait abnormalities would improve decision about when to do hindfoot or forefoot tendon transfers or lengthenings.

\section{CASE EXAMPLE}

Equinovarus foot deformity of the left foot in a hemiplegic cerebral palsy patient. After evaluating the patient with motion analysis and fine wire EMG, patient is treated with split tibialis posterior transfer to the peroneus brevis and heel cord lengthening (Fig. 5).

\section{Charcot-Marie-Tooth}

CMT is an inherited condition that affects the peripheral motor neurons. Patients often have progressive muscular weakness in the feet and legs. Common characteristics include foot drop, pes cavus, intrinsic muscle weakness and hammer toes that are routinely treated with tendon transfers, osteotomies and/or fusions. Application of foot and ankle gait analysis will improve understanding for surgical decision making and evaluation of the results (Fig. 6). ${ }^{[24,25]}$

\section{FUTURE DIRECTIONS}

\section{Fluoroscopic imaging system for foot and ankle motion analysis during walking}

Foot and ankle pathologies can be wide ranging and vary from congenital to neuromuscular. Currently radiographs, CT and MRI are used to view the foot in vivo though these only provide static images when often dynamic foot dysfunction is being treated. These techniques also lack the ability to accurately observe the motion of the subtalar joint which is responsible for the inversion/eversion and internal/external rotation of the hindfoot relative to the midfoot. Additionally, they fail to see the true interaction of a foot within a shoe, brace or orthotic. A fluoroscopic system designed specifically for studying the foot during gait can provide real-time motion views of the foot's internal structures and their relative interactions. Recent studies have modified fluoroscopic systems so that they can be mounted on the floor allowing an individual to walk between the emitter and collector triggering a series of images to be captured and assembled into a video displaying the motion (Fig. 7). Information gathered from this analysis will allow clinicians and researchers to more accurately identify atypical segmental foot motion, plan interventions, monitor progress and provide longer term care. 


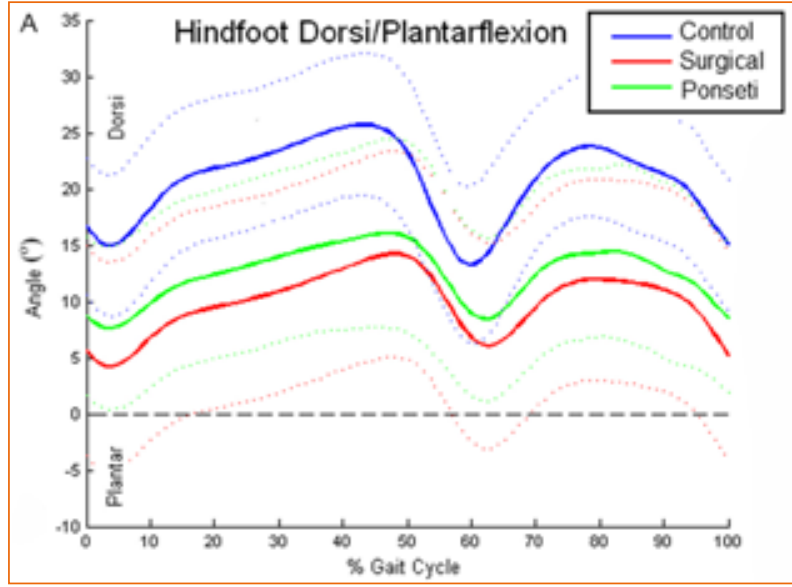

Şekil 3. Üç grup farklı yetişkin: kontroller (mavi), cerrahi olarak tedavi edilmiş clubfoot (kırmızı), ve Ponseti yöntemiyle tedavi edilmiş clubfoot (yeşil).

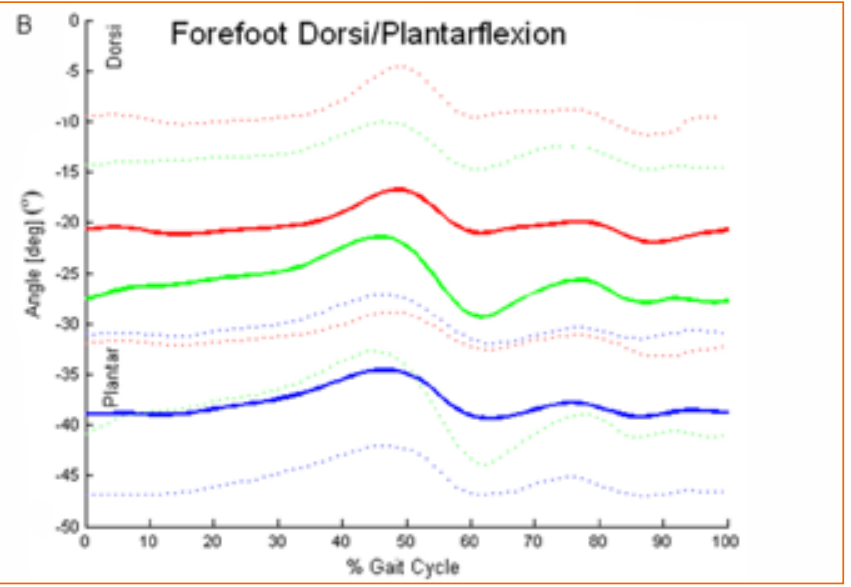

Figure 3. Plots of three groups of adults: Controls (blue), Clubfoot surgically treated (red), and those treated using Ponseti method (green).

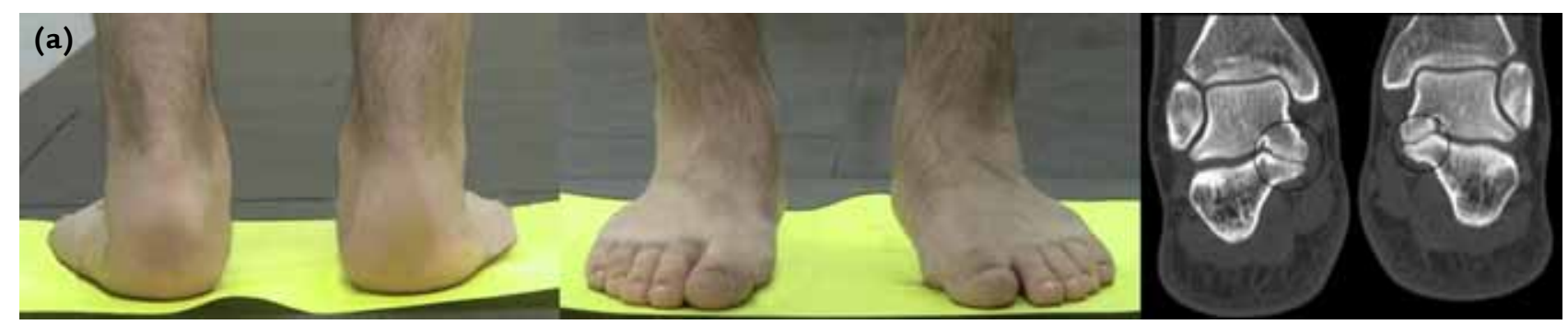

(b)

Coronal Hindfoot Kinematics

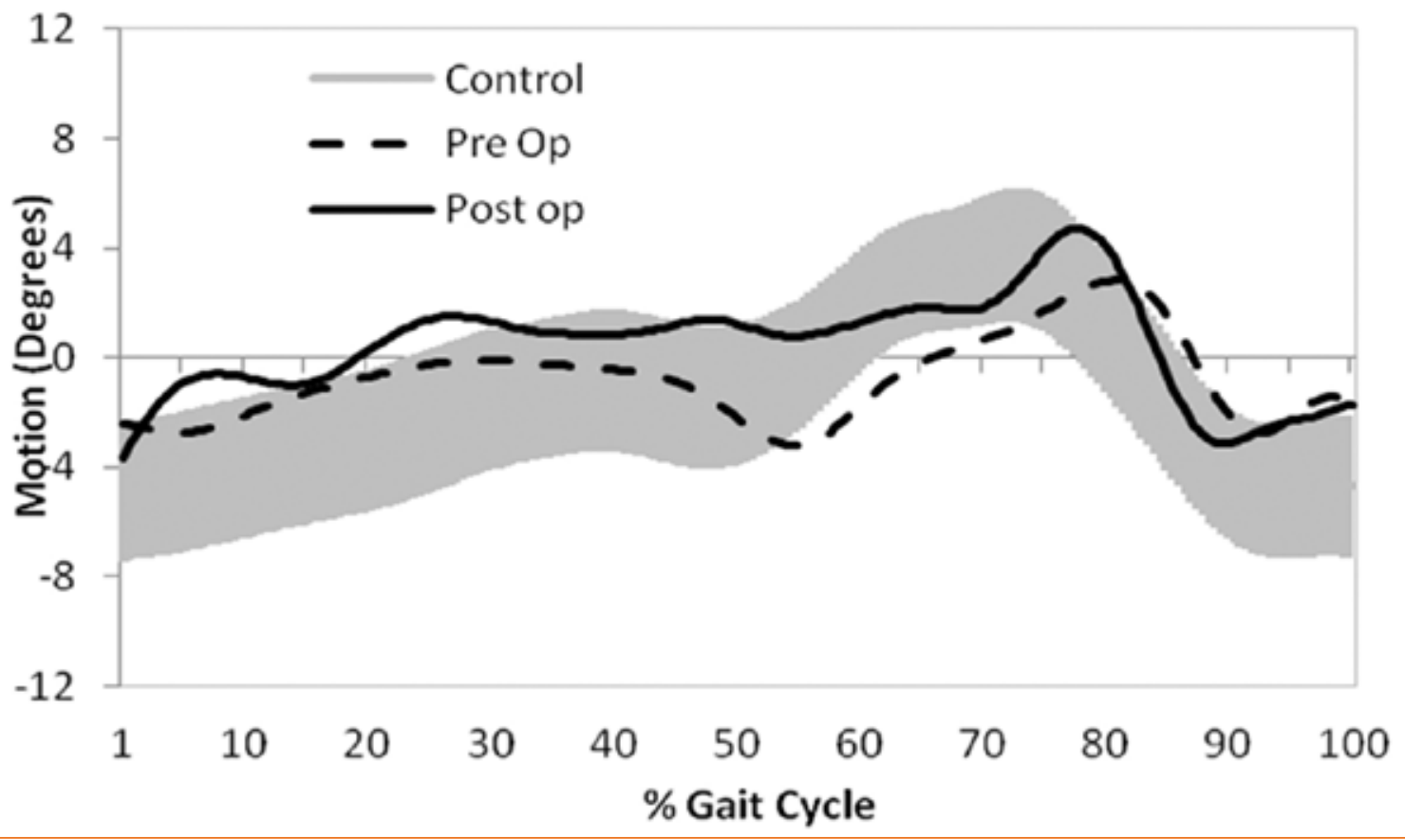

Şekil 4. a, b. Tarsal koalisyon fotoğrafları (a) ve arka ayak kinematiği (b).
Figure 4. a, b. Tarsal coalition photos (a) and hindfoot kinematics (b). 

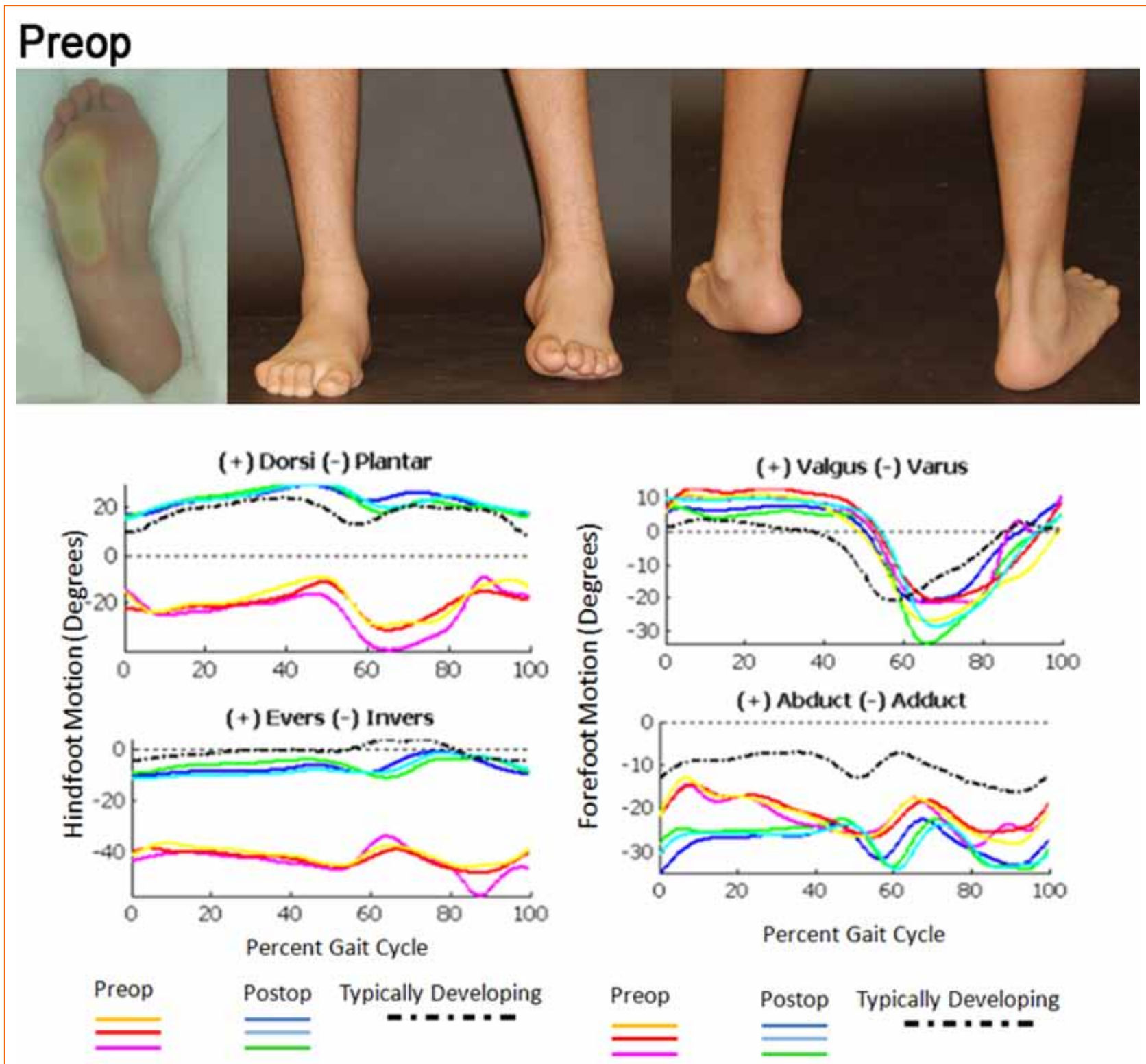

\section{Postop}

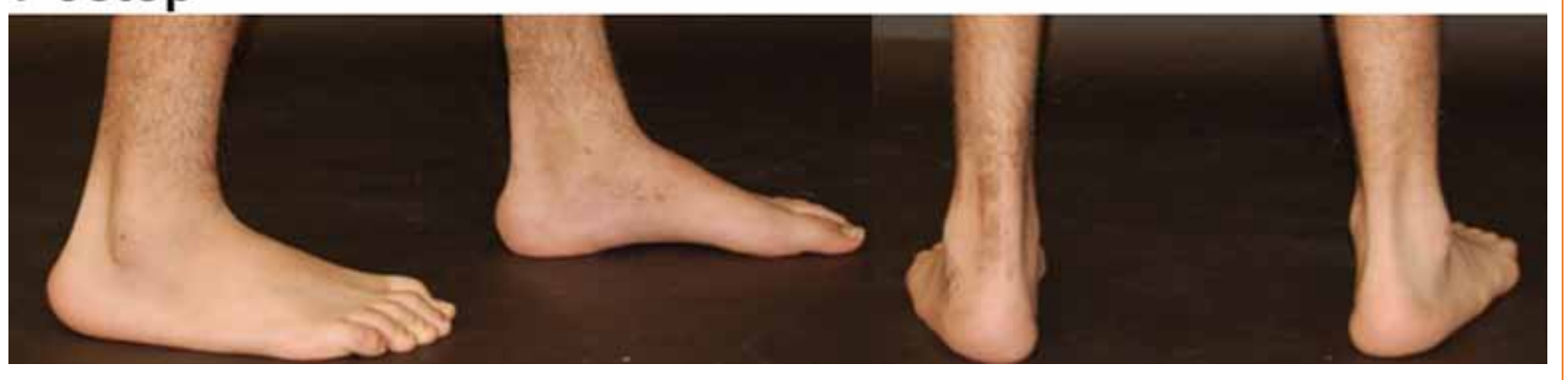

Şekil 5. Bir hemiplejik serebral palsili hastanın sol ayak ekinovarus ayak deformitesi.
Figure 5. Equinovarus foot deformity of the left foot in a hemiplegic cerebral palsy patient. 


\section{Preop}

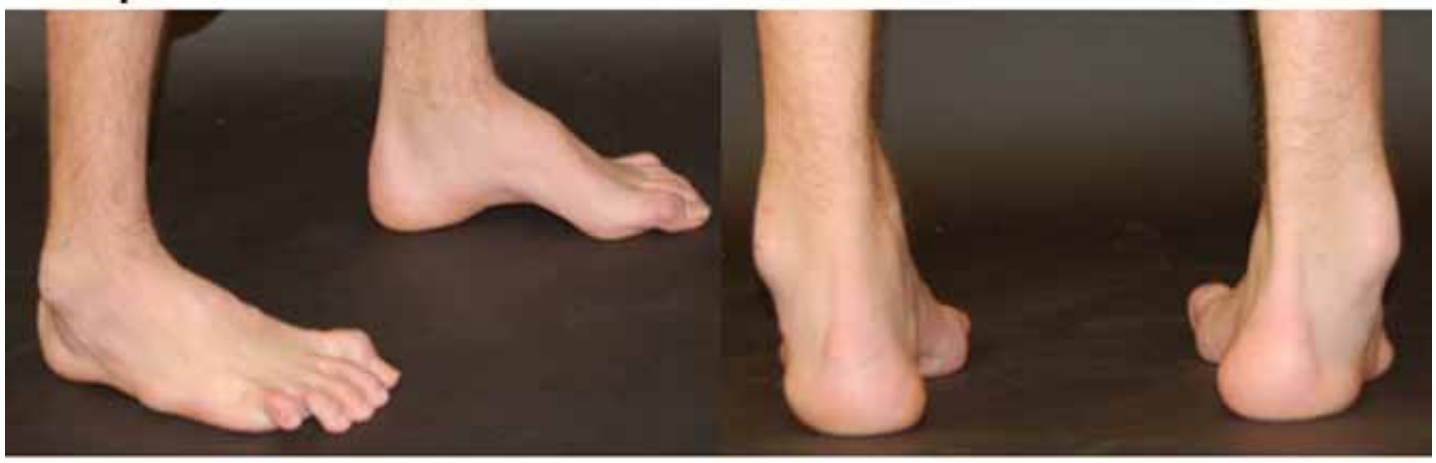

(+) Fwd (-) Bwd

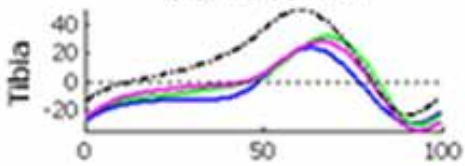

(+) Dorsi (-) Plantar

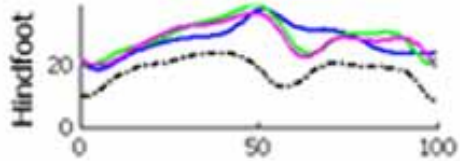

(+) Dorsi (-) Plantar

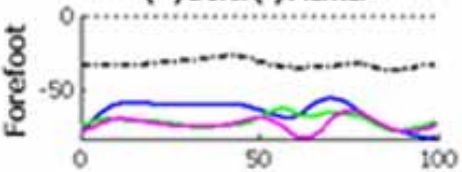

(+) Dorsi (-) Plantar

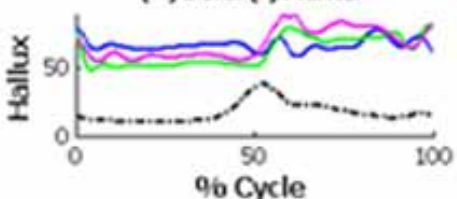

Postop
(+) Abduxt (-) Adduct

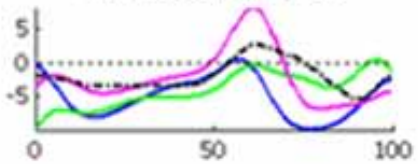

(+) Evers (-) Invers

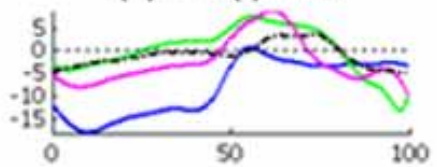

(+) Valous (-) Varus

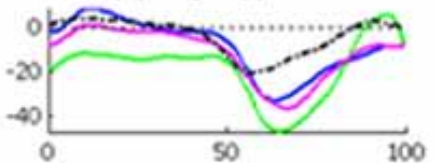

(+) Pronation (-) Suphation

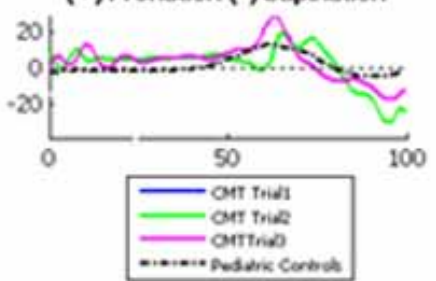

(+) Ext Rot (-) Int Rot

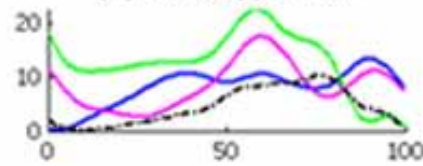

(+) Ext Rot (-) Int Rot

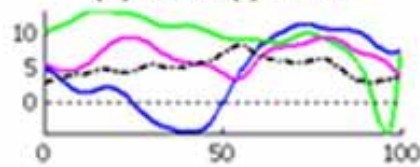

(+) Abduxt (-) Adduct

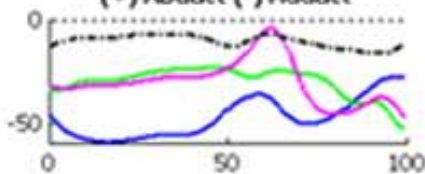

(+) Valgus (-) Varus

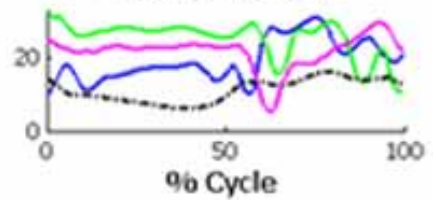

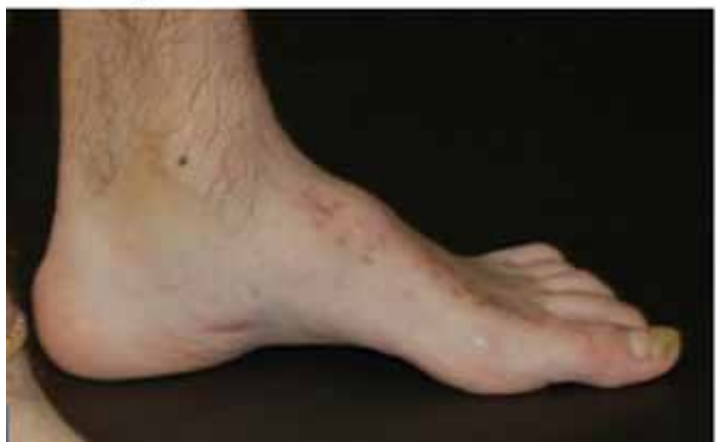

Figure 6. Cavovarus foot deformity in a patient with CharcotMarie-Tooth disease.

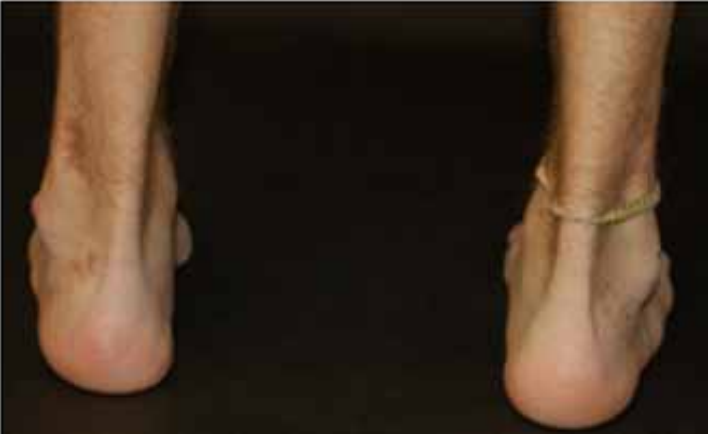

Figure 6. Cavovarus foot deformity in a patient with CharcotMarie-Tooth disease. 


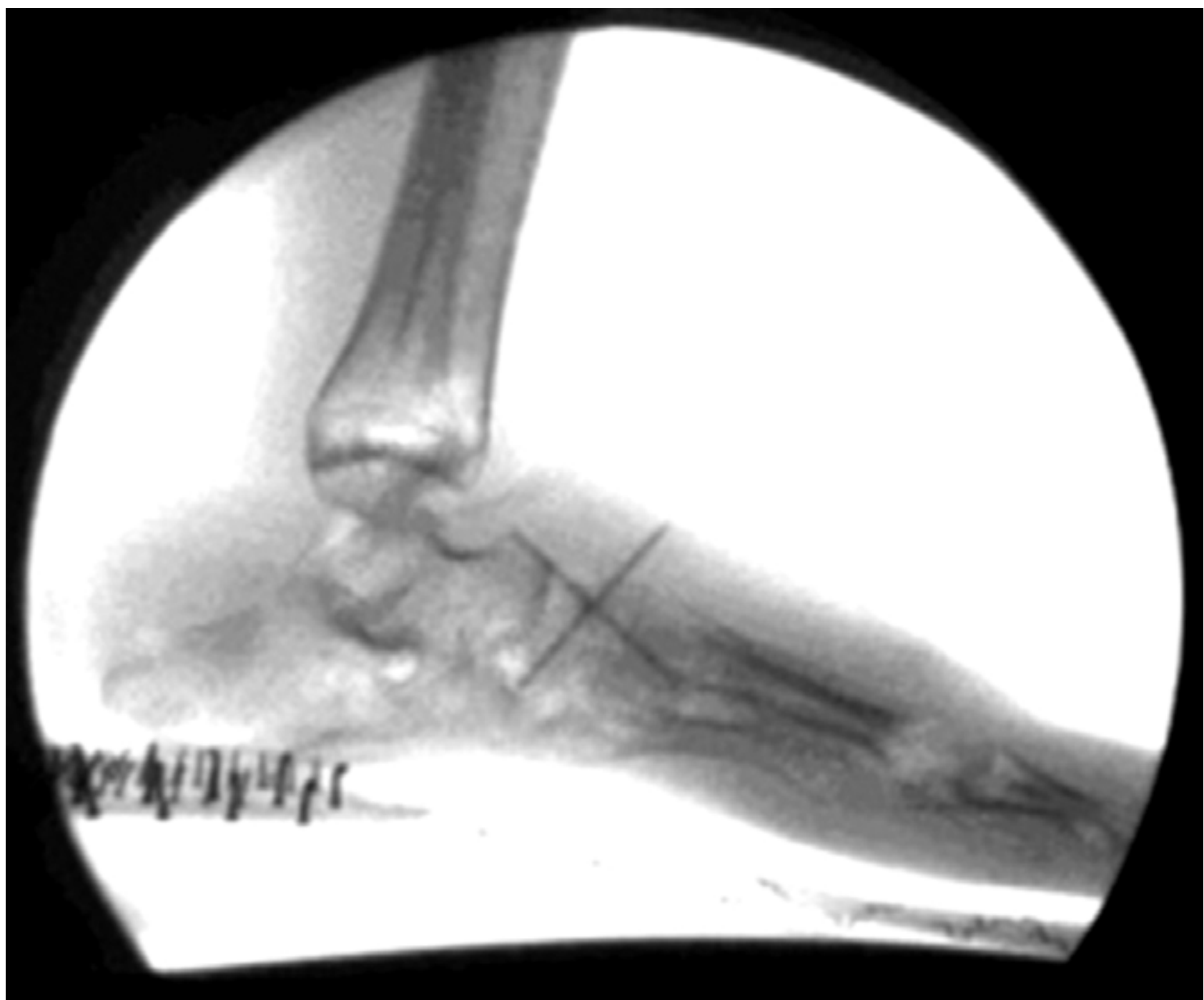

Şekil 7. Floroskopi sistemiyle çekilmiş ayak.

Figure 7. Shod foot captured by fluoroscopy system.

\section{KAYNAKLAR / REFERENCES}

1. Perry J, Burnfield JM. Gait Analysis: Normal and Pathological Function, 2nd ed. Thorofare, NJ: SLACK Incorporated; 2010.

2. Morris JM. Biomechanics of the foot and ankle. Clin Orthop Relat Res 1977;(122):10-7.

3. Inman VT. Joints of the Ankle, 2nd ed. Baltimore, MD: Williams and Wilkins; 1991.

4. Mann RA, Haskell A. Biomechanics of the Foot and Ankle. In: Coughlin MJ, Mann RA, Saltzman CL, editors. Surgery of the Foot and Ankle, 8th ed. Philadelphia: Mosby Elsevier; 2007. p.3-44.

5. Stebbins J, Harrington M, Thompson N, Zavatsky A, Theologis T. Gait compensations caused by foot deformity in cerebral palsy. Gait Posture 2010;32(2):226-30. CrossRef

6. Ballaz L, Plamondon S, Lemay M. Ankle range of motion is key to gait efficiency in adolescents with cerebral palsy. Clin Biomech (Bristol, Avon) 2010;25(9):944-8. CrossRef
7. Wren TA, Gorton GE 3rd, Ounpuu S, Tucker CA. Efficacy of clinical gait analysis: A systematic review. Gait Posture 2011;34(2):149-53. CrossRef

8. Davis R, Ounpuu S, Tyburski D, Gage JR. A gait analysis data collection and reduction technique. Human Movement Science 1991;10:575-87.

9. Rankine L, Long J, Canseco K, Harris GF. Multisegmental foot modeling: a review. Crit Rev Biomed Eng 2008;36(2-3):127-81.

10. Kadaba MP, Ramakrishnan HK, Wooten ME. Measurement of lower extremity kinematics during level walking. J Orthop Res 1990;8(3):383-92.

11. Nester CJ. Lessons from dynamic cadaver and invasive bone pin studies: do we know how the foot really moves during gait? J Foot Ankle Res 2009;2:18. CrossRef 
12. Nester $C$, Jones RK, Liu A, Howard D, Lundberg A, Arndt A, Lundgren P, StacoffA, Wolf P. Foot kinematics during walking measured using bone pins and surface mounted markers. J Biomech 2007;40(15):3412-23.

13. Grood ES, Suntay WJ. A joint coordinate system for the clinical description of three-dimensional motions: application to the knee. J Biomech Eng 1983;105(2):136-44.

14. Stebbins J, Harrington M, Thompson N, Zavatsky A, Theologis T. Repeatability of a model for measuring multi-segment foot kinematics in children. Gait Posture 2006;23(4):401-10.

15. Carson MC, Harrington ME, Thompson N, O'Connor JJ, Thoelogis TN. Kinematic analysis of a multi-segment foot mode for research and clinical applications: a repeatability analysis. J Biomech 2001;34(10):1299-307.

16. Kidder SM, Abuzzahab FS Jr, Harris GF, Johnson JE. A system for the analysis of foot and ankle kinematics during gait. IEEE Trans Rehabil Eng 1996;4(1):25-32.

17. Myers KA, Wang M, Marks RM, Harris GF. Validation of a multisegment foot and ankle kinematic model for pediatric gait. IEEE Trans Neural Syst Rehabil Eng 2004;12(1):122-30.

18. Johnson JE, Lamdan R, Granberry WF, Harris GF, Carrera GF. Hindfoot coronal alignment: a modified radiographic method. Foot Ankle Int 1999;20(12):818-25.

19. Long JT, Wang M, Winters JM, Harris GF. A multisegmental foot model with bone-based referencing: sensitivity to radiographic input parameters. Conf Proc IEEE Eng Med Biol Soc 2008;2008:879-82. CrossRef
20. Smith PA, Hassani S, GrafAN, Harris GF. Clinical Applications of Foot and Ankle Motion Analysis in Children, In: Harris GF, Smith PA, Marks RM, editors. Foot and Ankle Motion Analysis (Clinical Treatment and Technology). USA: CRC Press; 2008. p.21-45.

21. Smith PA, Kuo KN, Graf AN, Krzak J, Flanagan A, Hassani S, Caudill AK, Dietz FR, Morcuende J, Harris GF. Longterm results of comprehensive clubfoot release versus the Ponseti method: which is better? Clin Orthop Relat Res 2014;472(4):1281-90. CrossRef

22. Hetsroni I, Nyska M, Mann G, Rozenfeld G, Ayalon M. Subtalar kinematics following resection of tarsal coalition. Foot Ankle Int 2008;29(11):1088-94. CrossRef

23. Krzak JJ, Corcos DM, Graf A, Smith P, Harris GF. Effect of fine wire electrode insertion on gait patterns in children with hemiplegic cerebral palsy. Gait Posture 2013;37(2):251-7. CrossRef

24. Ward CM, Dolan LA, Bennett DL, Morcuende JA, Cooper RR. Long-term results of reconstruction for treatment of a flexible cavovarus foot in Charcot-Marie-Tooth disease. J Bone Joint Surg Am 2008;90(12):2631-42. CrossRef

25. Õunpuu S, Garibay E, Solomito M, Bell K, Pierz K, Thomson J, Acsadi G, DeLuca P. A comprehensive evaluation of the variation in ankle function during gait in children and youth with Charcot-Marie-Tooth disease. Gait Posture 2013;38(4):900-6. CrossRef 